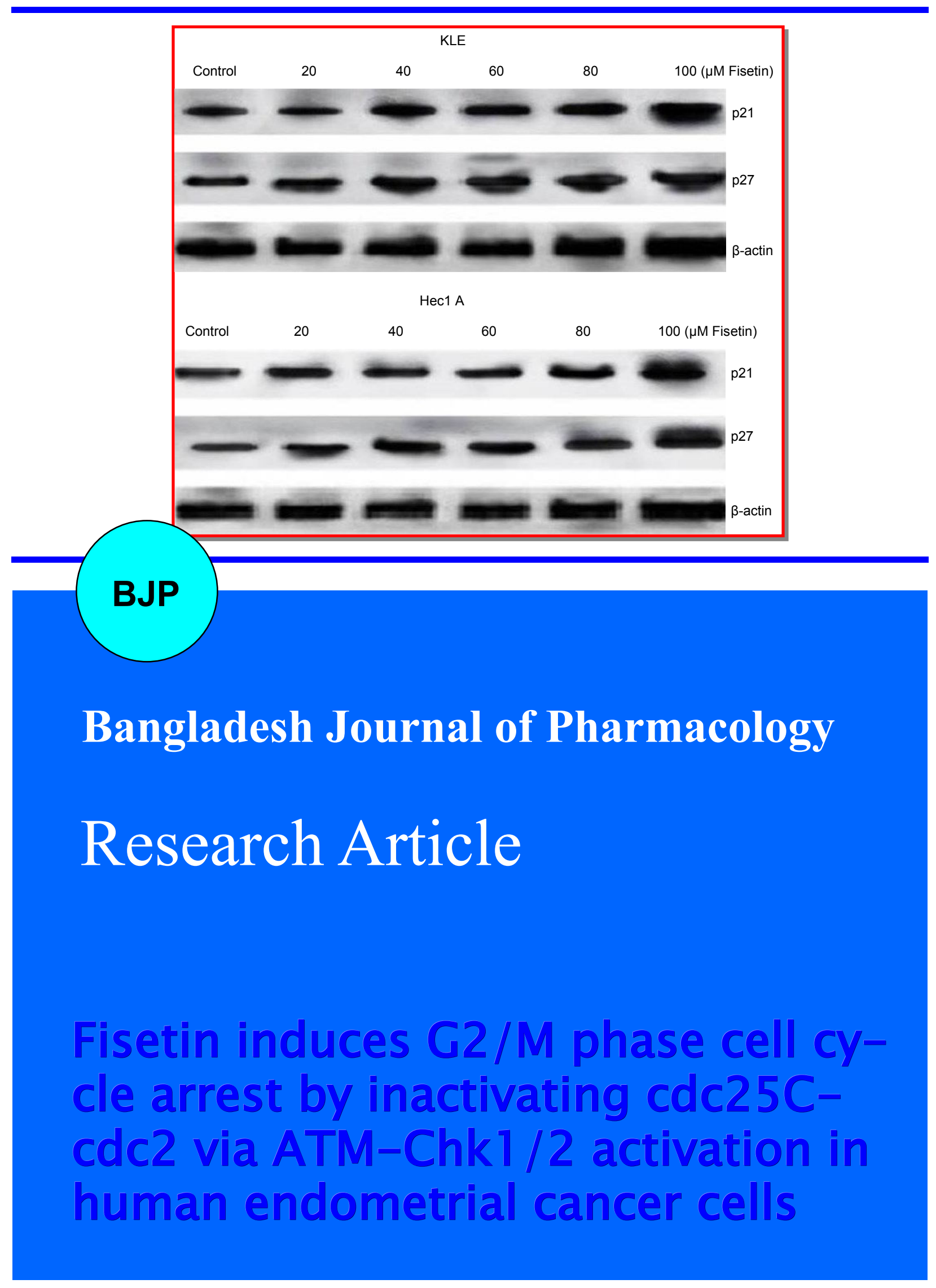




\title{
Fisetin induces G2/M phase cell cycle arrest by inactivating cdc25C -cdc2 via ATM-Chk1/2 activation in human endometrial cancer cells
}

\author{
Zhan-Ying Wang1, Wen-Qiong Liu' ${ }^{2}$, Si'e Wang1 and Zeng-Tao Wei ${ }^{1}$ \\ ${ }^{1}$ Department of Obstetrics and Gynecology, Jinan Central Hospital Affiliated to Shandong \\ University, Jinan 250013, China; ${ }^{2}$ Department of Obstetrics and Gynecology, The Affiliated Hospital of \\ Shandong University of Traditional Chinese Medicine, Jinan 250011, China.
}

\begin{tabular}{|c|c|}
\hline Article Info & \\
\hline Received: & 8 February 2015 \\
\hline Accepted: & 17 March 2015 \\
\hline Available Online: & 3 April 2015 \\
\hline DOI: $10.3329 /$ bjp. & $\mathrm{ji} 2.21945$ \\
\hline Cite this article: & \\
\hline Wang ZY, Liu W & Wang S, Wei ZT. \\
\hline $\begin{array}{l}\text { Fisetin induces G2 } \\
\text { arrest by inactivat }\end{array}$ & $\begin{array}{l}\text { M phase cell cycle } \\
\text { cdc25C-cdc2 via }\end{array}$ \\
\hline $\begin{array}{l}\text { ATM-Chk1/2 act } \\
\text { endometrial }\end{array}$ & $\begin{array}{l}\text { ation in human } \\
\text { ancer cells. }\end{array}$ \\
\hline $\begin{array}{l}\text { Bangladesh J Phar } \\
-87 \text {. }\end{array}$ & acol. 2015; 10: 279 \\
\hline
\end{tabular}

\begin{abstract}
Endometrial cancer is one of the most prevalent gynaecological malignancies where, currently available therapeutic options remain limited. Recently phyto -chemicals are exploited for their efficiency in cancer therapy. The present study investigates the anti-proliferative effect of fisetin, a flavonoid on human endometrial cancer cells (KLE and Hec1 A). Fisetin (20-100 $\mu \mathrm{M})$ effectively reduced the viability of Hec1 A and KLE cells and potentially altered the cell population at G2/M stage. Expression levels of the cell cycle proteins (cyclin B1, p-Cdc2, p-Cdc25C, p-Chk1, Chk2, p-ATM, cyclin B1, H2AX, p21 and p27) were analyzed. Fisetin suppressed cyclin B1 expression and caused inactivation of Cdc25C and Cdc2 by increasing their phosphorylation levels and further activated ATM, Chk1 and Chk2. Increased levels of p21 and p27 were observed as well. These results suggest that fisetin induced G2/M cell cycle arrest via inactivating $\mathrm{Cdc} 25 \mathrm{c}$ and Cdc2 through activation of ATM, Chk1 and Chk2.
\end{abstract}

\section{Introduction}

Endometrial cancer is one of the most prevailing gynecological malignancies with increasing incidence (Leslie et al., 2012) and with limited therapeutic options available for advanced and recurrent cancers.

Dysregulation of the cell cycle is the most frequent alterations in tumor development (Collins et al., 1997; Hajduch et al., 1999; Buolamwini, 2000). Among the cell cycle checkpoints, the G2/M checkpoint maintains chromosomal integrity by allowing cells to repair the DNA damage prior to mitosis and thus a target for development and identification of novel effective drugs.

DNA damage sensor, ataxia telangiectasia mutated (ATM) controls cell cycle arrest at G1 and G2 and blocks DNA synthesis that is in progress. The functions of ATM are mediated partly by checkpoint effector kinases, Chk1 and Chk2 (Zhou and Elledge, 2000; Kastan and Lim 2000; Abraham, 2001). ATM phosphorylates Chk2 on threonine 68 (Thr 68) and Chk1 on serine 317 and 345 (Ser 317 and Ser 345), causing their activation (Matsuoka et al., 1998; Melchionna et al., 2000). In response to DNA damage and DNA replication stress, Chk1 and Chk2 phosphorylate Cdc25C phosphatase, an activator of cyclin dependent kinase, Cdc2 (Bulavin et al., 2003).

Studies have reported the effect of various phytochemicals on carcinogenesis. Resveratrol (Aggarwal et al., 2004; Tyagi et al., 2006) and jaceosidin caused G2/M cell cycle arrests (Lee et al., 2013).

Fisetin, a flavonoid is commonly found in many fruits and vegetables as strawberries, apples and cucumbers (Kim et al., 2012). Recent investigations suggest that fisetin attenuated metastasis (Chou et al., 2013) and 
exerted anti-proliferative effects on various cancer cells (Chen et al., 2002; Haddad et al., 2006). Mechanisms by which fisetin acts on cancer cells though not completely understood, studies have reported that it reduces the cyclin D1 and E levels, increases p53 expression and activates caspase-3 (Chen et al., 2002; Lee et al., 2002, 2005; Lu et al., 2005; Haddad et al., 2006). This study is an attempt to explore the effect of fisetin on human endometrial cancer cells.

\section{Materials and Methods}

\section{Antibodies and reagents}

Fisetin and propidium iodide was purchased from Sigma (St. Louis, MO, USA). Antibodies for cyclin B1, phospho-Cdc2 (Tyr 15), Cdc2, phospho-ATM, p21, p27, and $\beta$-actin antibodies were purchased from Santa Cruz Biotechnology (Santa Cruz, CA, USA). Antibodies for phospho-Cdc25C (Ser 216), Cdc25C, phospho-H2AX (Ser 139), phospho- Chk1 and phospho-Chk2 were from Cell Signaling (Beverly, MA, USA). All other chemicals were obtained from Sigma (St. Louis, MO, USA) unless otherwise specified.

\section{Cell lines}

The endometrial cancer cell lines KLE and Hec1 A were obtained from American Type Culture Collection. Cells were cultured in DMEM media supple-mented with 5\% fetal bovine serum (FBS), penicillin $(100 \mu \mathrm{g} / \mathrm{mL})$ and streptomycin sulfate $(100 \mu \mathrm{g} / \mathrm{mL})$.

\section{Cell viability assay}

Cytotoxicity was assessed using MTT assay. Briefly, the cells $\left(5 \times 10^{5}\right)$ were seeded in DMEM media $(50 \mu \mathrm{L} /$ well) in a 96-well plate and incubated for $24 \mathrm{~h}$, followed by treatment with various concentrations of fisetin (20 $100 \mu \mathrm{M})$. After incubation for 48 hours, $25 \mu \mathrm{L}$ of MTT (5 $\mathrm{mg} / \mathrm{mL}$ stock solution) was added and the plates were further incubated for 4 hours. The blue colour formazan crystals formed after discarding the media, were dissolved in $50 \mu \mathrm{L}$ DMSO. Optical density was measured at $540 \mathrm{~nm}$ using a spectrophotometer (SpectraMax, Molecular Devices, Sunnyvale, CA, USA).

\section{Cell cycle analysis}

Endometrial cells (Hec1 A and KLE) were treated with fisetin $(20-100 \mu \mathrm{M})$. The cells were harvested following 6 and 12 hours of incubation and washed twice with ice cold PBS. The cells were fixed and permeabilised with $70 \%$ ice-cold ethanol at $4^{\circ} \mathrm{C}$ for $60 \mathrm{~min}$. The cells were washed once with PBS and re-suspended in a staining solution containing propidium iodide $(50 \mu \mathrm{L} / \mathrm{mL})$ and RNase A $(250 \mu \mathrm{g} / \mathrm{mL})$. The cell suspensions were incubated for $30 \mathrm{~min}$ at room temperature followed by fluorescence-activated cell sor-ting (FACS) cater-plus flow cytometry (Becton Dickin-son Co., Germany) using 10,000 cells per treatment group.

\section{Western blot analysis}

Cells were washed with cold PBS and lysed using cell lysis buffer (25 mM Tris $\mathrm{HCl}$ pH 7.6, $150 \mathrm{mM} \mathrm{NaCl}, 1 \%$ NP-40, $1 \%$ sodium deoxycholate, $0.1 \%$ SDS) for $30 \mathrm{~min}$ on ice. Total protein content was determined using protein assay kit of Invitrogen ${ }^{\mathrm{TM}}$, Life technologies. Clear protein lysates $(30-80 \mu \mathrm{g})$ were then fractionated by SDS-PAGE (8-12\%) and electro-transferred to nitrocellulose membranes. The mem-branes were blocked with $5 \%$ non fat milk in PBST buffer (PBS, $\mathrm{pH}=$ 7.3 and $0.05 \%$ Tween-20) and incubi-ted overnight at $4^{\circ}$ $\mathrm{C}$ with primary antibodies, followed by hybridization with horseradish peroxidise conjuga-ted secondary antibodies. The bands were detected by enhanced chemiluminescence (GE Healthcare). The band signals of proteins were normalized to those of $\beta$-actin (internal control).

\section{Statistical analysis}

The data are expressed as mean \pm standard deviation (SD). The significance of the differ-ence between different groups was determined using one-way analysis of variance (one-way ANOVA) using SPSS software (version 17.0). The differences were considered significant at $\mathrm{p}<0.05$.

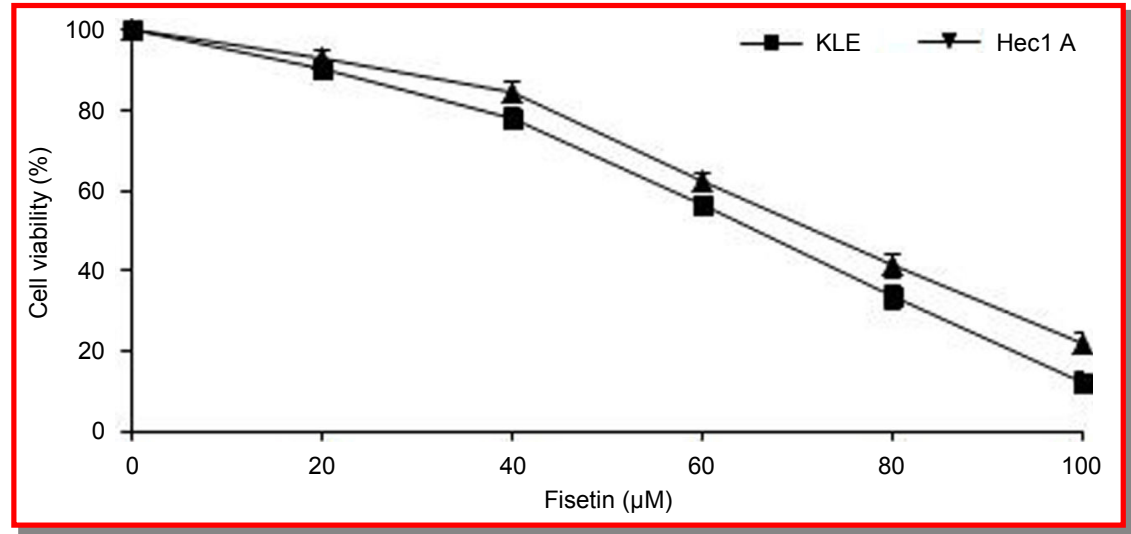

Figure 1: Fisetin inhibits the growth of endometrial cancer cells -KLE and Hec1 A

Fisetin effectively reduced the viability of KLE and Hec1 A cells.Values are represented as mean \pm S.D from 3 individual experiments 


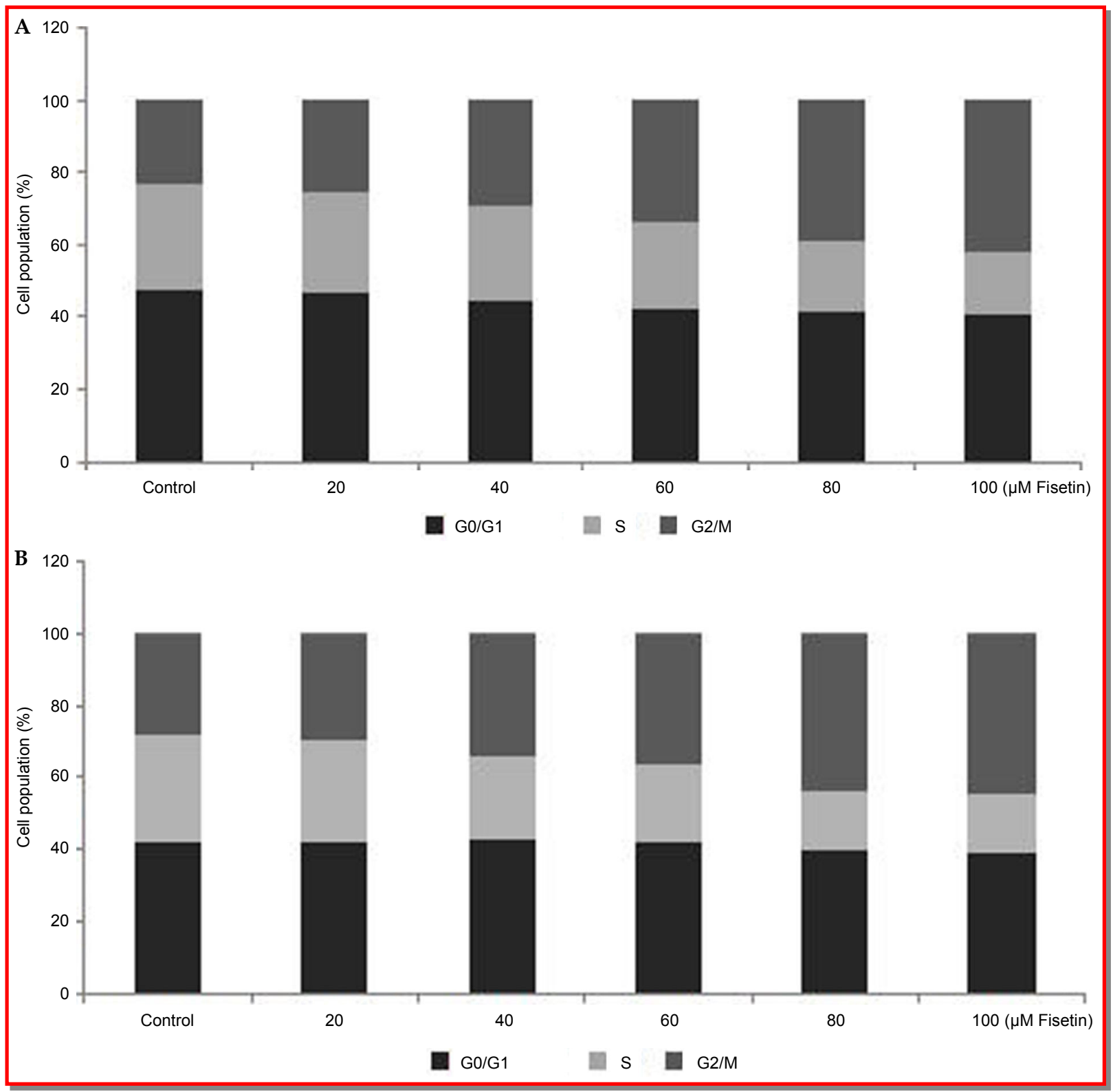

Figure 2: Effect of fisetin on cell cycle in KLE cells

Fisetin at (20-100 $\mu \mathrm{M})$ induces G2/M cell cycle arrest in KLE cells in a dose and time-dependent manner. The increase in G2/M cells following fisetin exposure at 12 hours (A) were higher than at 6 hours exposure (B)

\section{Results}

The anti-proliferative effect of fisetin on KLE and Hec1 A cells were assessed by MTT assay (Figure 1). Following treatment with $20 \mu \mathrm{M}$ fisetin, the viability was 90.3\% in Hec1A cells and 92.8\% in KLE cells. However, with increasing concentrations of fisetin, the viable cell count sharply decreased thus exerting a dose-dependent effect in the viability of cancer cells. At $100 \mu \mathrm{M}$ fisetin exhibited a multi-fold decrease in the viable cell number compared to the lower concentrations (20 and $40 \mu \mathrm{M})$. While the anti-proliferative effect was evident from the observed results, fisetin caused a more marked decline in the viability of $\mathrm{Hec} 1 \mathrm{~A}$ than KLE cells.
To determine whether the growth inhibitory effect is associated with cell cycle arrest, the distribution of cells in each phase of the cell cycle was analyzed using flow cytometry. As depicted in Figures 2 and Figure 3, exposure of KLE and Hec1 A cells to growth suppressive concentrations of fiestin $(20-100 \mu \mathrm{M})$ resulted in a significant increase in $\mathrm{G} 2 / \mathrm{M}$ fraction. After treatment with $100 \mu \mathrm{M}$ fisetin for 6 and 12 hours, the percentage of cells in the G2/M phase was 42.1 and $44.8 \%$ respectively in KLE cells and 44.16 and $45.90 \%$ in the Hec1 A cells (Figures 2,3).

Furthermore, the G2/M arrest induced by fisetin was observed to occur in a time- and dose-dependent 


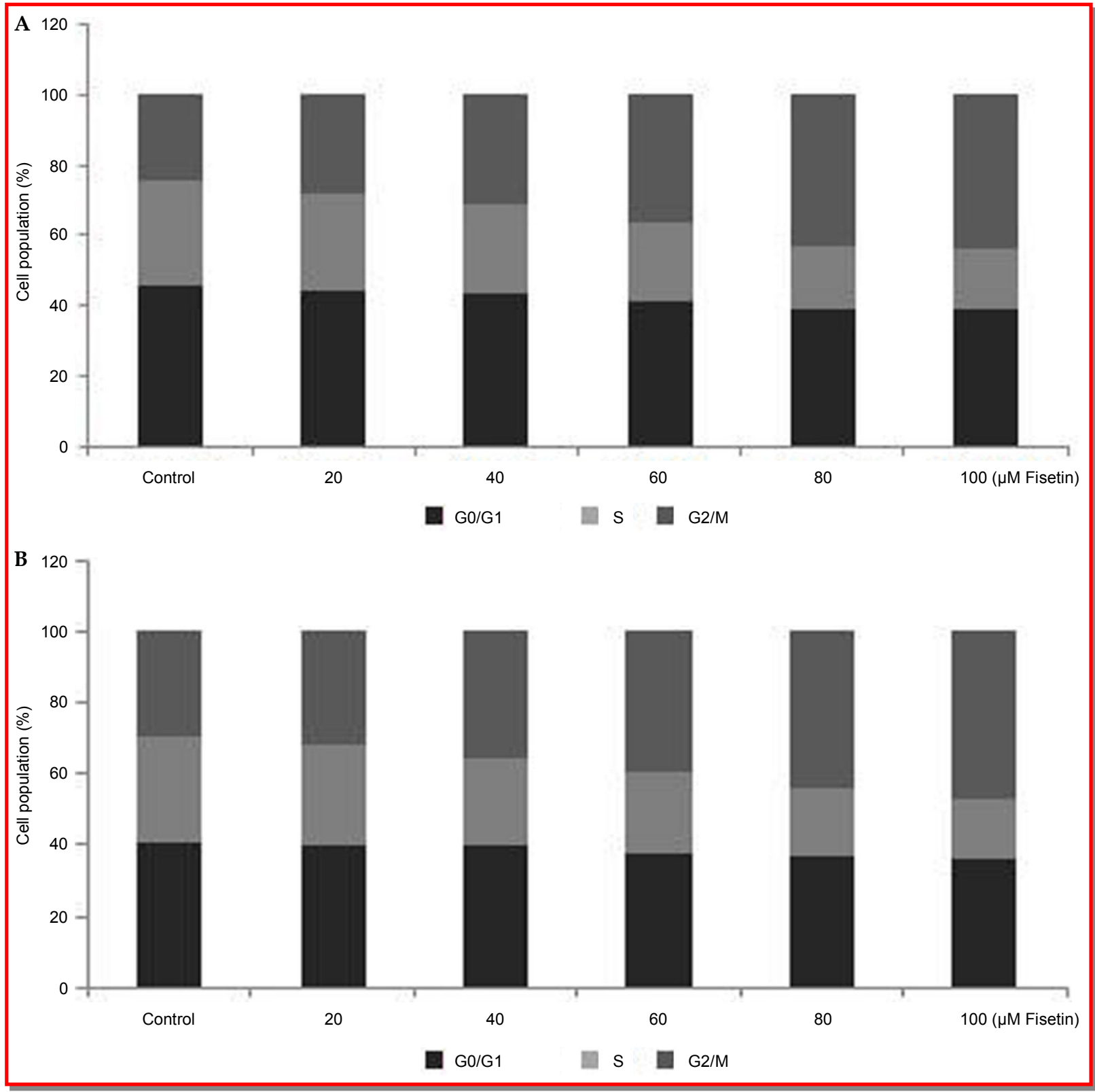

Figure 3: Influence of fisetin on cell cycle in Hec1 A cells

Exposure to fisetin at (20 -100 $\mu \mathrm{M})$ for 6 hours (A) and 12 hours (B) induces G2/M cell cycle arrest in a time and dose-dependent manner

manner. The number of cells at G2/M phase following 12 hours exposure was higher than 6 hours exposure to fisetin in both KLE and Hec1 A. However, as in cell viability, the cell cycle arrest was more pronounced in Hec1 A than KLE cells. In our study, fisetin exposure induced significant increase in $\mathrm{G} 2 / \mathrm{M}$ fraction and this was accompanied by a decrease in $G_{0} / G_{1}$ and $S$ phase cells. This indicates that the cell inhibitory effect of fisetin against the proliferation of KLE and Hec1 A cells is correlated with cell-cycle arrest.

Cyclins, cyclin-dependent kinases (CDKs) and their inhibitors regulate cell cycle progression and arrest. Cyclin B1 and Cdc2 form a complex and co-operate to promote the $\mathrm{G} 2 / \mathrm{M}$ phase transition. We investigated whether exposure to fisetin at $20-100 \mu \mathrm{M}$ for 12 hours affected the expression of cyclin B1 and Cdc2 in cancer cells. Treatment with fisetin considerably suppressed the levels of cyclin B1 and induced a remarkable increase in the phosphorylation of Cdc2 at Tyr 15 (Figure 4). The expression of cyclin B1 decreased nearly 2 -fold on exposure to fisetin at $100 \mu \mathrm{M}$. Enhanced levels of phosphorylation of Cdc2 at Tyr 15 suppresses its kinase activity and reduces the expression levels of cyclin B1 and subsequently leads to the inactivation of Cdc2-cyclinB1 kinase complex, thereby causing cell cycle arrest. Further, Cdc25C phosphatase regulates the phosphorylation state of Cdc2 at Tyr 15. The phospho- 


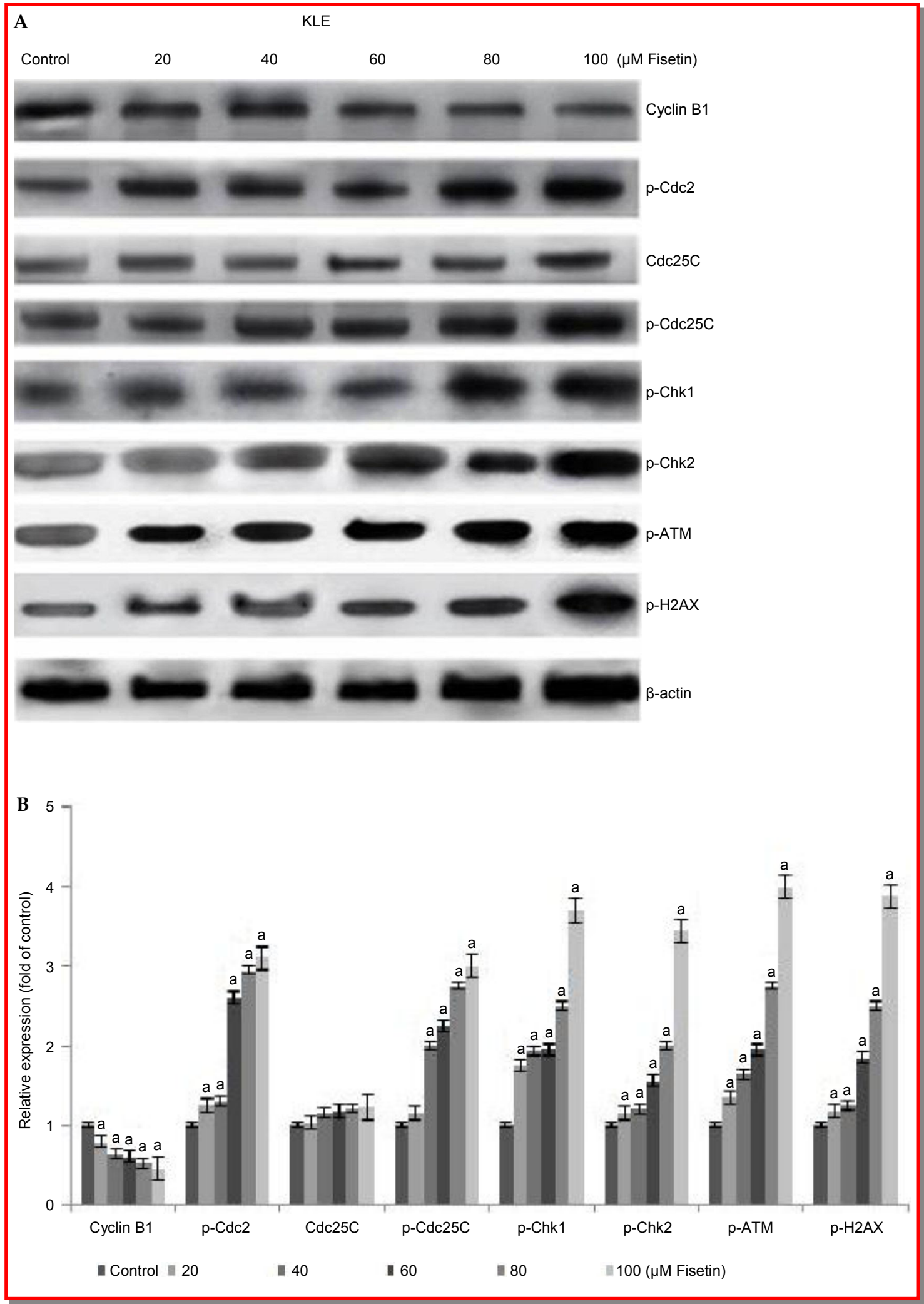

Figure 4: Fisetin modulates the expressions of cell cycle regulatory proteins

Fisetin at various concentrations modulates the expressions of cell cycle regulatory proteins in KLE (A, B) and Hec1 A cells (C, D) and causes G2/M cell cycle arrest.Values are presented as mean \pm S.D from 3 individual experiments. arepresents statistical significance at $\mathrm{p}<0.05$ compared against control as determined by one-way ANOVA 

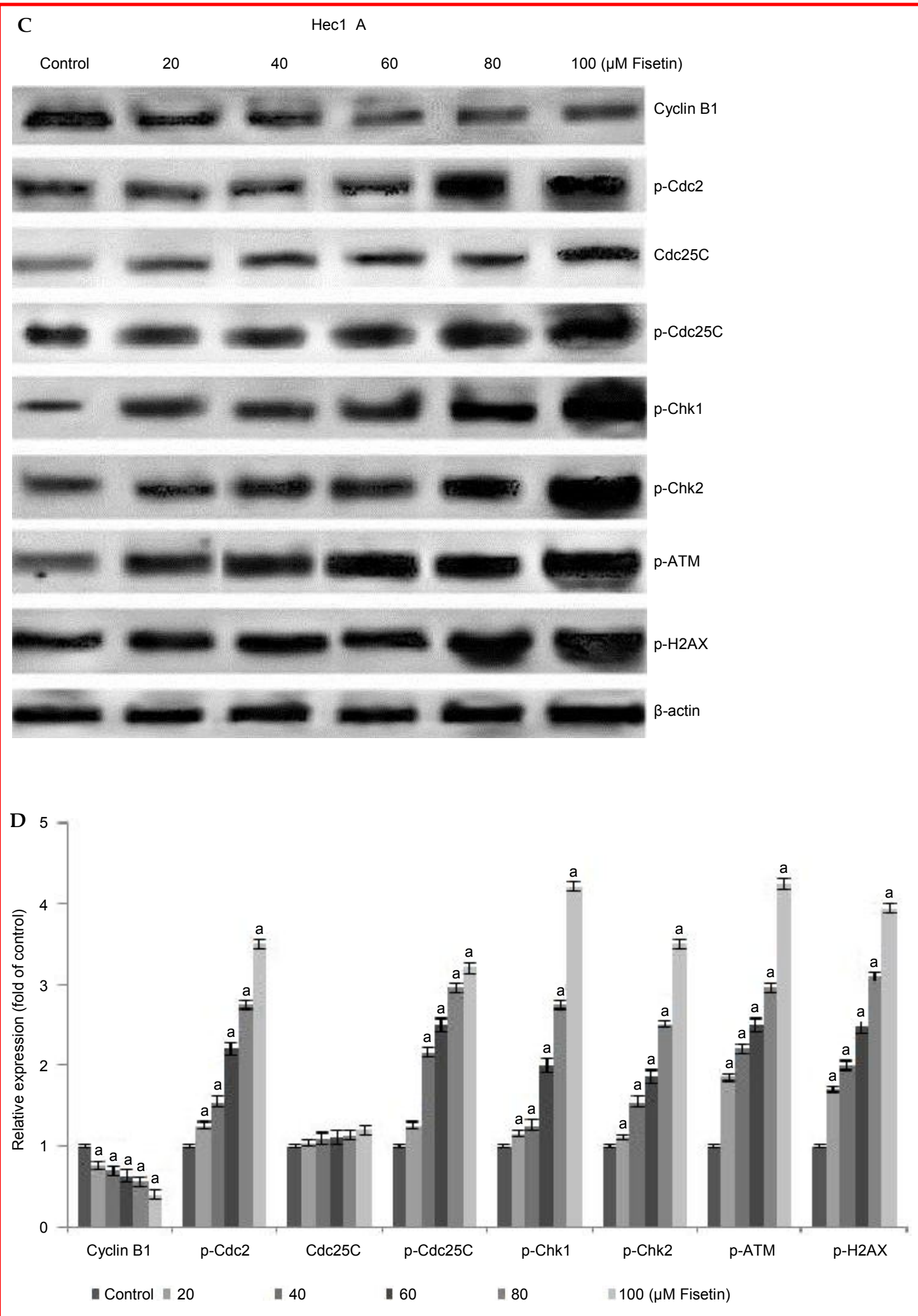

Figure 4: Fisetin modulates the expressions of cell cycle regulatory proteins (Cont.)

Fisetin at various concentrations modulates the expressions of cell cycle regulatory proteins in KLE (A, B) and Hec1 A cells (C, D) and causes G2/M cell cycle arrest. Values are presented as mean \pm S.D from 3 individual experiments. arepresents statistical significance at $\mathrm{p}<0.05$ compared against control as determined by one-way ANOVA 


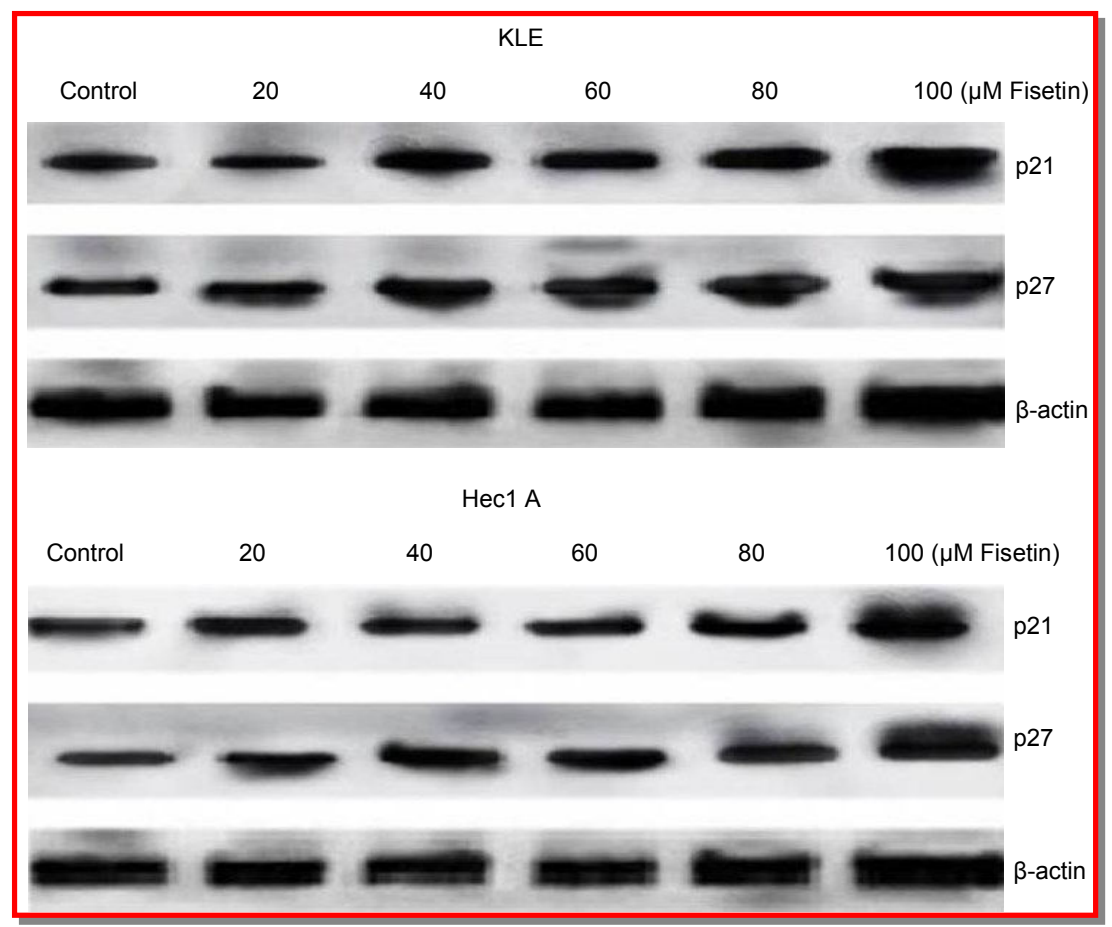

Figure 5: Fisetin induces the expressions of p21 and p27

Fisetin at various concentrations induced the expressions of cell cycle inhibitor proteins p21 and p27 in KLE (upper) and Hec1 A cells (lower) and causes G2/M cell cycle arrest.Values are presented as mean \pm S.D from 3 individual experiments. arepresents statistical significance at $\mathrm{p}<0.05$ compared against control as determined by one-way ANOVA

rylation of Cdc25C following treatment with fisetin at 20-100 $\mu \mathrm{M}$ was determined. The level of p-Cdc25C (Ser 216) was notably increased on fisetin treatment (Figure 4) while the levels of Cdc25C remained not much altered. The results suggest that fisetin-induced G2/M arrest is associated with the negative regulation of cyclin B1 and Cdc2 in Hec1A and KLE cells.

Chk1/2 kinases act up-stream of Cdc25C (Matsuoka et al., 1998). As shown in Figure 4, fisetin markedly upregulated the phosphorylation status of Chk $1 / 2$ kinases. The elevated expression of $\mathrm{Chk} 1 / 2$ kinases was observed to occur in a dose-dependent manner in both Hec1A and KLE cells. Thus could be suggested that the loss of Cdc25C phosphatase activity observed can result from the phosphorylation of inhibitory sites by Chk1/2. ATM kinases are central in triggering cellular responses to DNA damage/genotoxic stress in eukaryotic cells (Kastan and Lim, 2000; Shiloh, 2003) and are known to activate Chk1 and Chk2 (Khanna et al., 2001). We examined the expression of p-ATM on exposure to fisetin. Fisetin treatment of cells for 12 hours resulted in a strong increase in the levels of p-ATM protein, which showed that ATM was activated. Further, fisetin caused increased serine 139 phosphorylation of histone H2AX that is phosphorylated by ATM upon its activation by phosphorylation. These results suggest that fisetininduced G2/M phase arrest involves ATM checkpoint signalling.
Fisetin treatment markedly increased both p21 and p27 expressions in Hec1 A and KLE cells in a dose-dependent manner (Figure 5). The levels of p21 and p27 increased multifold on exposure to $100 \mu \mathrm{M}$ fisetin when compared to the expression levels following treatment with $20 \mu \mathrm{M}$ fisetin. In addition p21 and p27 expression was more pronounced in Hec1 A than KLE cells. Furthermore, p21 expression was higher than p27 upon fisetin treatment in both Hec1 A and in KLE cells.

\section{Discussion}

In our study, fisetin was observed to effectively modulate the levels of cyclin B1 and p-Cdc2. Fisetin induced marked elevations in the phophorylated forms of Cdc25C which could have caused raised p-Cdc2 levels thus ultimately leading to their inactivation and cell cycle arrest.

Phosphorylation of Cdc25C is controlled by Chk1 and Chk2 (Bartek and Lukas, 2003). However activity of Chk1 and Chk2 are regulated by ATM, which in turn is activated in response to DNA damage. Activated ATM results in the activation of Chk1 and Chk2 by phosphorylation, and also stabilizes p53 by phosphorylation (Al Rashid et al., 2011).

Fisetin caused a significant increase in p-ATM levels 
thus indicating ATM activation which induces phospho -rylation of Chk1 (Ser 345) and Chk2 (Ser 516) and also phosphorylation of Cdc25C (Ser 216) and Cdc2 (Tyr 15). Furthermore, in our study, fisetin exposure resulted in phosphorylation of H2AX (Histone H2A), a substrate of ATM kinases. H2AX phosphorylation is a major and early response to double-stranded DNA breaks (DSBs) (Fernandez-Capetillo et al., 2003). ATM kinase induces phosphorylation of ser 139 on the histone H2AX tail and the subsequent rapid formation of H2AX foci at the DSB sites (Redon et al., 2002). These observations suggest that fisetin may possibly cause a DNA damage response.

We also assessed the role of p21 and p27 in fisetininduced G2/M arrest. p21WAF1/CIP1, a member of the cyclin dependent kinase inhibitor (CDKI) family plays a role in both the G1 and G2 checkpoints (Harper et al., 1993; Ando et al., 2001). Fisetin at various concentrations caused a significant increase in p21 and p27 expression both in KLE and Hec1 A cells suggesting that it effectively blocks cell cycle progression.

Development of novel therapeutic agents is a critical need of today for the treatment and survival of patients with late-stage and recurrent endometrial cancer (Garai et al., 2006). Increasing amount of evidence suggests that certain phytochemicals have marked cancer chemopreventive properties (Waladkhani and Clemens, 1998; Kelloff et al., 2000). Observations of the present investigation suggest that fisetin strongly inhibits cell cycle progression by causing G2/M cell cycle arrest. The findings of the study are in line with previous reports (Park et al., 2009; Shin et al., 2011; Lee et al., 2013) demonstrating the significance of flavonoids inhibiting cell growth.

In conclusion, fisetin effectively causes $\mathrm{G} 2 / \mathrm{M}$ cell cycle arrest by modulating the expression of vital cell cycle regulating proteins- cdc25C-cdc2 via ATM-Chk1/2 activation.

\section{References}

Abraham RT. Cell cycle checkpoint signaling through the ATM and ATR kinases. Genes Dev. 2001; 15: 2177-96.

Aggarwal BB, Bhardwaj A, Aggarwal RS, Seeram NP, Shishodia S, Takada Y. Role of resveratrol in prevention and therapy of cancer: Preclinical and clinical studies. Anticancer Res. 2004; 24: 2783-840.

Al Rashid ST, Harding SM, Law C, Coackley C, Bristow RG. Protein-protein interactions occur between p53 phosphoforms and ATM and 53BP1 at sites of exogenous DNA damage. Radiat Res. 2011; 175: 588-98.

Ando T, Kawabe T, Ohara H, Ducommun B, Itoh M, Okamoto $\mathrm{T}$. Involvement of the interaction between p21 and proliferating cell nuclear antigen for the maintenance of $\mathrm{G} 2 / \mathrm{M}$ arrest after DNA damage. J Biol Chem. 2001; 276: 42971-77.
Bartek J, Lukas J. Chk1 and Chk2 kinases in checkpoint control and cancer. Cancer Cell 2003; 3: 421-42.

Bulavin DV, Higashimoto Y, Demidenko ZN, Meek S, Graves P, Phillips C, Zhao H, Moody SA, Appella E, PiwnicaWorms H, Fornace AJ Jr. Dual phosphorylation controls Cdc25 phosphatases and mitotic entry. Nat Cell Biol. 2003; 6: 545-51.

Buolamwini JK. Cell cycle molecular targets in novel anticancer drug discovery. Curr Pharm Des. 2000; 6: 379-92.

Chen YC, Shen SC, Lee WR, Lin HY, Ko CH, Shih CM, Yang LL. Wogonin and fisetin induction of apoptosis through activation of caspase 3 cascade and alternative expression of p21 protein in hepatocellular carcinoma cells SK-HEP-1. Arch Toxicol. 2002; 76: 351-59.

Chou RH, Hsieh SC, Yu YL, Huang MH, Huang YC, Hsieh $\mathrm{YH}$. Fisetin inhibits migration and invasion of human cervical cancer cells by down-regulating urokinase plasminogen activator expression through suppressing the p38 MAPK-dependent NF-kB signaling pathway. PLoS ONE 2013; 8: e71983.

Collins K, Jacks T, Pavletich NP. The cell cycle and cancer. Proc Natl Acad Sci USA 1997; 94: 2776-78.

Fernandez-Capetillo O, Mahadevaiah SK, Celeste A, Romanienko PJ, Camerini-Otero RD, Bonner WM, Manova $\mathrm{K}$, Burgoyne P, Nussenzweig A. H2AX is required for chromatin remodeling and inactivation of sex chromosomes in male mouse meiosis. Dev Cell 2003; 4: 497-508.

Garai J, Molnar V, Varga T, Koppan M, Torok A, Bodis J. Endometriosis: harmful survival of an ectopic tissue. Front Biosci. 2006; 11: 595-619.

Haddad AQ, Venkateswaran V, Viswanathan L, Teahan SJ, Fleshner NE, Klotz LH. Novel antiproliferative flavonoids induce cell cycle arrest in human prostate cancer cell lines. Prostate Cancer Prostatic Dis. 2006; 9: 68-76.

Hajduch M, Havlieek L, Vesely J, Novotny R, Mihal V, Strnad M. Synthetic cyclin dependent kinase inhibitors: New generation of potent anticancer drugs. Adv Exp Med Biol. 1999; 457: 341-53.

Harper JW, Adami GR, Wei N, Keyomarsi K, Elledge SJ. The p21 Cdk interacting protein Cip1 is a potent inhibitor of G1 cyclin-dependent kinases. Cell 1993; 75: 805-16.

Kastan MB, Lim DS. The many substrates and functions of ATM. Nat Rev Mol Cell Biol. 2000; 1: 179-86.

Kelloff GJ, Crowell JA, Steele VE, Lubet RA, Malone WA, Boone CW, Kopelovich L, Hawk ET, Lieberman R, Lawrence JA, Ali I, Viner JL, Sigman CC. Progress in cancer chemoprevention: development of diet-derived chemopreventive agents. J Nutr. 2000; 130: 467S-71S.

Khanna KK, Lavin MF, Jackson SP, Mulhern TD. ATM, a central controller of cellular responses to DNA damage. Cell Death Differ. 2001; 8: 1052-65.

Kim HJ, Kim SH, Yun JM. Fisetin inhibits hyperglycemiainduced proinflammatory cytokine production by epigenetic mechanisms. Evid Based Complement Alternat Med. 2012; 639-49.

Lee Y, Bae EJ. Inhibition of mitotic clonal expansion mediates 
fisetin-exerted prevention of adipocyte differentiation in 3T3 -L1 cells. Arch Pharm Res. 2013; 36: 1377-84.

Lee WR, Shen SC, Lin HY, Hou WC, Yang LL, Chen YC. Wogonin and fisetin induce apoptosis in human promyeloleukemic cells, accompanied by a decrease of reactive oxygen species, and activation of caspase 3 and $\mathrm{Ca}^{2+}$ -dependent endonuclease. Biochem Pharmacol. 2002; 63: 225 -36 .

Lee HG, Yu KA, Oh WK, Baeg TW, Oh HC, Ahn JS, Jang WC, Kim JW, Lim JS, Choe YK, Yoon DY. Inhibitory effect of jaceosidin isolated from Artemisiaargyi on the function of E6 and E7 oncoproteins of HPV 16. J Ethnopharmacol. 2005; 98: 339-43.

Lee JG, Kim JH, Ahn JH, Lee KT, Baek NI, Choi JH. Jaceosidin, isolated from dietary mugwort (Artemisia princeps), induces G2/M cell cycle arrest by inactivating cdc $25 \mathrm{C}$-cdc2 via ATM -Chk1/2 activation. Food Chem Toxicol. 2013; 55: 214-21.

Leslie KK. Endometrial Cancer. Obstet Gynecol Clin North Am. 2012; 39: 255-68.

Lu X, Jung J, Cho HJ, Lim DY, Lee HS, Chun HS, Kwon DY, Park JH. Fisetin inhibits the activities of cyclin-dependent kinases leading to cell cycle arrest in HT-29 human colon cancer cells. J Nutr. 2005; 135: 2884-90.

Matsuoka S, Huang M, Elledge SJ. Linkage of ATM to cell cycle regulation by the Chk2 protein kinase. Science 1998; 282: 1893-97.
Melchionna $\mathrm{R}$, Chen $\mathrm{XB}$, Blasina A, McGowan $\mathrm{CH}$. Threonine 68 is required for radiation-induced phosphorylation and activation of Cds1. Nat Cell Biol. 2000; 2: 762-65.

Park I, Park KK, Park JH, Chung WY. Isoliquiritigenin induces G2 and M phase arrest by inducing DNA damage and by inhibiting the metaphase/ anaphase transition. Cancer Lett. 2009; 277: 174-81.

Redon C, Pilch D, Rogakou E, Sedelnikova O, Newrock K, Bonner W. Histone H2A variants H2AX and H2AZ. Curr Opin Genet Dev. 2002; 12: 162-69.

Shiloh Y. ATM and related protein kinases: Safe guarding genome integrity. Nat Rev Cancer 2003; 3: 155-68.

Shin SY, Hyun J, Yu JR, Lim Y, Lee YH. 5-Methoxyflavanone induces cell cycle arrest at the G2/M phase, apoptosis and autophagy in HCT116 human colon cancer cells. Toxicol Appl Pharmacol. 2011; 254: 288-98.

Tyagi A, Singh RP, Agarwal C, Siriwardana S, Sclafani RA, Agarwal R. Resveratrol causes Cdc2-tyr15 phosphorylation via ATM/ATR-Chk1/2-Cdc25C pathway as a central mechanism for $\mathrm{S}$ phase arrest in human ovarian carcinoma Ovcar-3 cells. Carcinogenesis 2005; 26: 1978-87.

Waladkhani AR, Clemens MR. Effect of dietary phytochemicals on cancer development. Int J Mol Med. 1998; 1: 747-53.

Zhou BB, Elledge SJ. The DNA damage response: Putting checkpoints in perspective. Nature 2000; 408: 433-39. 


\section{Your feedback about this paper}

1. Number of times you have read this paper 0

2. Quality of paper Click

3. Your comments 